Sains Malaysiana 49(7)(2020): 1491-1498

http://dx.doi.org/10.17576/jsm-2020-4907-02

\title{
Frictional Properties of the Wax Coverings in Nepenthes alata Slippery Zone: Results from AFM Scanning
}

(Sifat Geseran Penutup Lilin di Zon Licin Nepenthes alata: Hasil daripada Pengimbasan AFM)

\author{
LiXIN WANG*, SHUOYAN ZHANG, LinLin ZHANG \& SHANSHAN Li
}

\begin{abstract}
Slippery zone of Nepenthes alata presents anisotropic friction behaviors depending on its evolved structures. Studies have demonstrated the contribution of lunate cells, but the role of wax coverings has not been specially investigated. In this paper, we showed findings obtained from AFM scanning and SEM observation on characterizing the frictional properties of wax coverings. Friction data generated by the AFM cantilever on wax coverings along downward and upward directions were different. The difference was insignificant (2.56\%) when applying the load force of $300 \mathrm{nN}$, but increased (4.83-8.40\%) when applying the load force of 500-1500 $\mathrm{nN}$. The scanned wax coverings showed no detectable damage when applying the load force of $300 \mathrm{nN}$, whereas observable damage was presented when the load force exceeded $500 \mathrm{nN}$. When the load force increased to $1500 \mathrm{nN}$, the wax coverings were destroyed completely. The results suggest the wax coverings depend on their surface morphology and structural characteristic to generate different frictional properties in different directions, but the difference was inconspicuous to declare the surface anisotropy. This study is helpful for further understanding the anisotropic properties of slippery zone, and motivates the slippery zone to be a bionic prototype for designing anisotropic surfaces.
\end{abstract}

Keywords: Biotribology; frictional properties; slippery zone; surface anisotropy; wax coverings

ABSTRAK

Zon licin Nepenthes alata menunjukkan tingkah laku geseran anisotropik bergantung pada strukturnya yang berkembang. Kajian telah menunjukkan sumbangan sel-sel lunat, tetapi peranan penutup lilin belum dikaji secara khusus. Dalam makalah ini, kami menunjukkan penemuan yang diperoleh daripada pengimbasan AFM dan pemerhatian SEM mengenai ciri sifat geseran penutup lilin. Data geseran yang dihasilkan oleh julur AFM pada penutup lilin pada arah bawah dan atas adalah berbeza. Perbezaannya tidak bererti (2.56\%) apabila menggunakan daya beban $300 \mathrm{nN}$, tetapi meningkat (4.83-8.40\%) ketika menggunakan daya beban 500-1500 nN. Penutup lilin yang diimbas tidak menunjukkan kerosakan boleh kesan ketika menerapkan daya beban $300 \mathrm{nN}$, sedangkan kerosakan boleh kesan ditunjukkan ketika daya beban melebihi $500 \mathrm{nN}$. Apabila daya beban meningkat kepada $1500 \mathrm{nN}$, penutup lilin hancur sepenuhnya. Keputusan kajian menunjukkan penutup lilin bergantung pada morfologi permukaan dan ciri strukturnya untuk menghasilkan sifat geseran yang berlainan dalam arah yang berbeza, tetapi perbezaannya tidak jelas untuk menyatakan anisotropi permukaan. Kajian ini berguna untuk lebih memahami sifat anisotropik zon licin, dan mendorong zon licin untuk menjadi prototip bionik bagi merancang permukaan anisotropik.

Kata kunci: Anisotropi permukaan; biotribologi; penutup lilin; sifat geseran; zon licin

\section{INTRODUCTION}

Nepenthes plants have evolved pitchers growing from the tips of their conspicuous leaves to efficiently capture insects (Ellison \& Gotelli 2009, 2001), which provide almost the entire nutrients required to survive in the infertile habitats (Bonn \& Federle 2004; Juniper \& Burras 1962; Moran 1996; Moran et al. 1999; Thornham et al. 2012). Considering the observable difference in macromorphology and microstructure, the pitchers can be typically distinguished by four parts: A leaf-shaped lid, a collar-formed peristome, a slippery zone and a digestive zone (Benz et al. 2012; Gaume \& Giusto 2009; Gaume et al. 2002; Moran \& Clarke 2010; Page \& Lennon 1999). Evolutionarily optimized, these parts perform the functions of attracting and trapping insects, retaining and digesting prey, absorbing and transporting the derived nutrients. Recently, both morphological structures and predation functions of the pitchers have become a hot subject for studies of anti-attachment mechanism (Bauer et al. 2009; Wang \& Zhou 2010), bionic models for the development of insect slippery trapping plate (Wang \& Zhou 2014; Wang et al. 2009) and functional surfaces with unidirectional liquid transport or superhydrophobic properties (Chen et al. 2017, 2016; Wang et al. 2018a, 2018b; Wong et al. 2011), and bioinspired materials with anti-adhesive properties (Koch et al. 2009).

For most Nepenthes species, the slippery zone locating closely below the peristome possesses a great number of downward-directed lunate cells and a dense layer of irregular wax coverings (Pant \& Bhatnagar 
1977; Riedel et al. 2007, 2003). The singly distributed lunate cell with both ends bent towards the pitcher bottom corresponds to an exclusive and enlarged overlapping guard cell, generating a crescent-shaped and convex asymmetrical profile. Bobisut (1910) and Knoll (1914) initially postulated that the lunate cells depend on their crescent-shaped projections with asymmetrical profiles to make the slippery zone present anisotropic properties, enabling insects grasp when turned the slippery zone upside down. Behavioral observation showed that the lunate cells interfere considerably with insect locomotion, as the vertical-oriented lunate cells (their ends towards digestive zone) can prohibit insect claws from grasping, whereas such structures provide steady anchorages for claw attachment when the slippery zone is inverted (Gaume et al. 2004, 2002). Recent studies have demonstrated that the lunate cells contribute significantly to the surface anisotropy of slippery zone in term of beetle attachment, making the claw-structured beetle slide more easily in a vertical-directed slippery zone, but showing strong grasping behavior in an inverted slippery zone (Gorb \& Gorb 2011). Recent findings confirmed that the lunate cells rely on their anisotropic structures to greatly influence insect attachment capability, as just $6 \%$ of the experimental ants are able to escape from the upwardfixed slippery zone, whereas $58 \%$ escaped when the slippery zone is inverted, and the friction forces generated by climbing crickets in the slippery zone along downward direction are 2 to 3 times of those along upward direction (Zhang et al. 2015). Zhang et al. (2015) characterized the surface anisotropy of slippery zone in term of insect attachment behaviors, and intuitively assumed the lunate cells were the causation, but they have not conducted investigations to include or exclude the contribution of wax coverings yet. Therefore, the mechanism behind the anisotropy phenomena of Nepenthes alata slippery zone is still unknown.
The wax coverings consist of numerous plateletshaped crystals with irregular profile, and a recent investigation with AFM scanning showed that the wax coverings can withstand the load force up to $250 \mathrm{nN}$ (Scholz et al. 2010). However, the study did not show the frictional information of wax coverings, and all previous studies have not focused on the frictional properties (anisotropy or isotropy) of the wax coverings. In our study, the frictional information of wax coverings along downward and upward directions was acquired via atomic force microscopy (AFM) scanning, and micromorphology of the scanned wax coverings was examined with scanning electron microscopy (SEM), and then the contribution of the wax coverings to the anisotropic properties of slippery zone was analyzed. The obtained results can fully reveal the anisotropy mechanism of Nepenthes alata slippery zone, and motivate the slippery zone to be a bionic porotype for developing bioinspired surfaces with fine anisotropic properties.

\section{MATERIALS AND METHODS}

\section{PITCHERS}

Mature pitchers (Figure 1(a)) of Nepenthes alata were used to investigate the frictional properties of wax coverings. The $N$. alata plants were commercially obtained from a nursery (Hangzhou City, China) and bred in a small greenhouse under continuously controlled environmental conditions at a temperature of $26-30{ }^{\circ} \mathrm{C}$ and a relative humidity of $60-80 \%$. In growing, the pitchers were more or less contaminated by various contaminations, such as dust and wing scales of trapped insects. Therefore, each of the selected pitchers was carefully rinsed with distilled water to remove contaminations. These prepared slippery zones were used for AFM scanning and SEM examination.
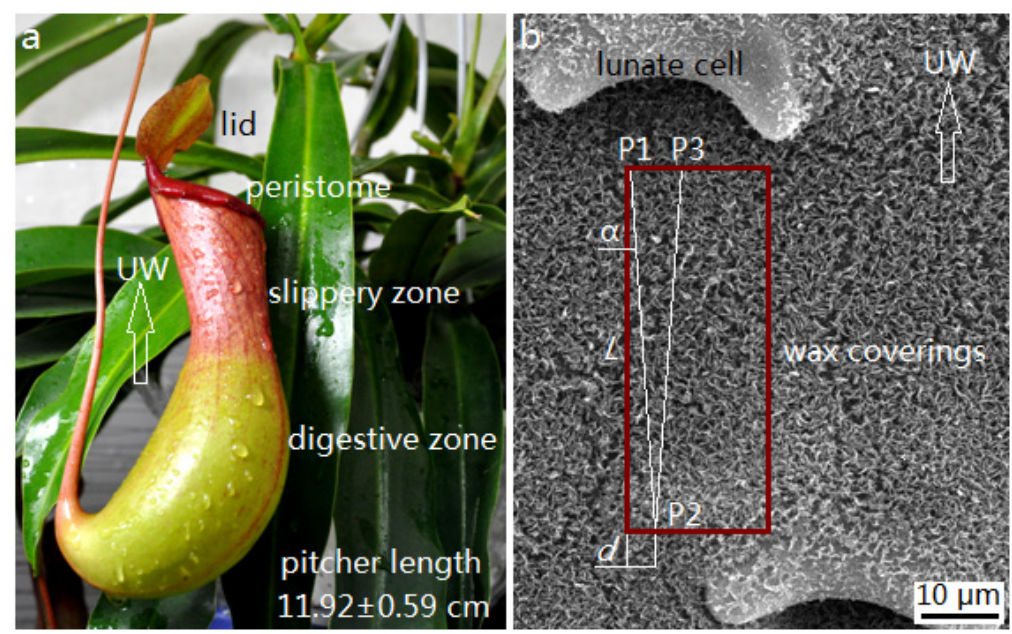

FIGURE 1. Macrostructures of the Nepenthes alata pitcher (a) and a schematic depiction showing the trajectory of AFM cantilever during the trace and retrace scanning (b). Number of measurements of the pitcher length $\mathrm{n}=8$. Trace: from P1 to P2, along downward (towards digestive zone) direction; Retrace: from P2 to P3, along upward (towards peristome) direction; P1,

P2 and P3: starting and finishing point of the AFM scanning; $L$ : length of the scanning region; $d$ : scanning width, equals to the diameter of the cantilever tip, $30 \mathrm{~nm}$; UW: upward direction; $\alpha$ : the inclined angle between the scanning trajectory and the scanning region, $\tan \alpha=d / L$, the length of scanning region was $4 \mu \mathrm{m}$, and the $\alpha$ was $0.43^{\circ}$ 


\section{AFM SCANNING}

An AFM apparatus (MFP-3D classic, Asylum Research, Oxford instrument Co., UK) was used to perform the AFM scanning. A high reflection coated triangular silicon nitride cantilever (Multi75E-G, Bugdetsensor, Nanoworld, Switzerland) was used to generate the frictional information on wax coverings. Typical characteristics of the cantilever mainly include a nominal force constant of $3.0 \mathrm{~N} / \mathrm{m}$, a four sided pyramidal tip with a tip angle of $30^{\circ}$ (centerline-to-side), and a tip diameter of $30 \mathrm{~nm}$.

Specimen $\left(2.0-2.5 \mathrm{~cm}^{2}\right)$ was freshly cut from the prepared slippery zones and glued to a circular glass slide, and its periphery submerged in ultrapure water to avoid the structural shrink caused by water evaporation. The scanning was performed in contact mode with a constant scanning velocity of $1.0 \mu \mathrm{m} / \mathrm{s}$, and the load force applied to the AFM cantilever was adjusted to 300, 500, 800,1200 , and $1500 \mathrm{nN}$, respectively. When scanning on the wax coverings, the friction data generated by the cantilever tip under these load forces can be recorded. The direction of the Trace trajectory (P1 to P2) equaled to along the downward direction, and direction of the Retrace trajectory (P2 to P3) equaled to along the upward direction (Figure 1(b)). Because the singly distributed lunate cells are characterised by a large value in height $(18-22 \mu \mathrm{m})$ and a small value in space length (about 85-103 $\mu \mathrm{m}$ ) (Wang \& Zhou 2016, 2011; Wang et al. 2016), the movement of AFM cantilever is frequently interrupted, thus the scanning region was adjusted to $4 \times 1$ $\mu \mathrm{m}^{2}$. The AFM scanning was conducted at a temperature of $26^{\circ} \mathrm{C}$ and a relative humidity of $30 \%$.

The AFM scanning information was analyzed via the software (Igor Pro V6.36, Asylum Research, Oxford instrument Co., UK) belonging to the AFM apparatus. From the saved Trace and Retrace images, the frictional information generated by the AFM cantilever scanned on the wax coverings along downward (Trace) and upward (Retrace) directions was exported, namely the friction data. Because of the rather small inclined angle ( $\alpha=0.43^{\circ}$, Figure $1(\mathrm{~b})$ ), the scanning trajectory was considered exactly along the downward or upward direction.

\section{SEM EXAMINATION}

To investigate the damage degree of the wax coverings scanned by the AFM cantilever under various load forces, micromorphology of the wax coverings was examined. Further, to find the scanned wax coverings much more easily, the scanning region of AFM cantilever was adjusted to $20 \mu \mathrm{m}^{2} \times 10 \mu \mathrm{m}^{2}$. Several pieces $\left(1 \mathrm{~cm}^{2}\right)$ of the scanned slippery zone were selected, and dried with a method of critical point drying. The dried specimens were sputter-coated with palladium (Precision Etching Coating Machine, Gatan 682 PECS, Gatan Inc., USA), and then observed via a SEM apparatus (Hitachi S-3400N, Hitachi Corp., Japan). To exhibit the original (without critical point drying and sputter-coated) morphology of wax coverings, specimens were cut from the rinsed slippery zone and mounted on an aluminum block, and directly observed with the SEM equipment. The examination was conducted at a temperature of $26^{\circ} \mathrm{C}$ and a relative humidity of $30 \%$.

\section{RESULTS AND DISCUSSION}

\section{FRICTION DATA PROVIDED BY AFM SCANNING}

The friction data provided a possibility to declare the frictional properties (anisotropy or isotropy) of wax coverings. The friction data showed a growing tendency with the increasing of the load force, and the friction along upward (Retrace, towards peristome) direction was always higher than that along downward (Trace, towards digestive zone) direction (Figure 2). Under all these selected load forces, the friction data of the AFM cantilever scanned on wax coverings along the two directions were different. The difference was rather insignificant (2.56\%; Figure 2(a); Table 1) when the AFM cantilever was applied with the load force of 300 $\mathrm{nN}$, but it became much more observable (4.83-8.40\%; Figure 2(b)-2(d); Table 1) when applying the load force of 500-1200 nN. However, the friction data (Figure 2(e)) and the degree of difference $(7.47 \%)$ (Table 1$)$ decreased slightly when the load force was adjusted to $1500 \mathrm{nN}$. Consequently, under various load forces, the wax coverings caused the AFM cantilever to generate different friction data along downward and upward directions, but these differences were not conspicuous, even rather insignificant.

TABLE 1. Friction data of the AFM cantilever on wax coverings of Nepenthes alata slippery zone

\begin{tabular}{|c|c|c|c|c|c|c|}
\hline Load force/ $\mathrm{nN}$ & & 300 & 500 & 800 & 1200 & 1500 \\
\hline \multirow[t]{2}{*}{ Friction data/ V } & Retrace & $1.369 \pm 0.008$ & $1.366 \pm 0.008$ & $0.537 \pm 0.006$ & $0.565 \pm 0.012$ & $0.556 \pm 0.006$ \\
\hline & Trace & $1.335 \pm 0.014$ & $1.303 \pm 0.022$ & $0.507 \pm 0.013$ & $0.521 \pm 0.010$ & $0.517 \pm 0.013$ \\
\hline$\left(F d_{\mathrm{RT}}-F d_{\mathrm{T}}\right) / F d_{\mathrm{T}} / \%$ & & 2.56 & 4.83 & 5.98 & 8.40 & 7.47 \\
\hline
\end{tabular}

data in Retrace and Trace scanning 

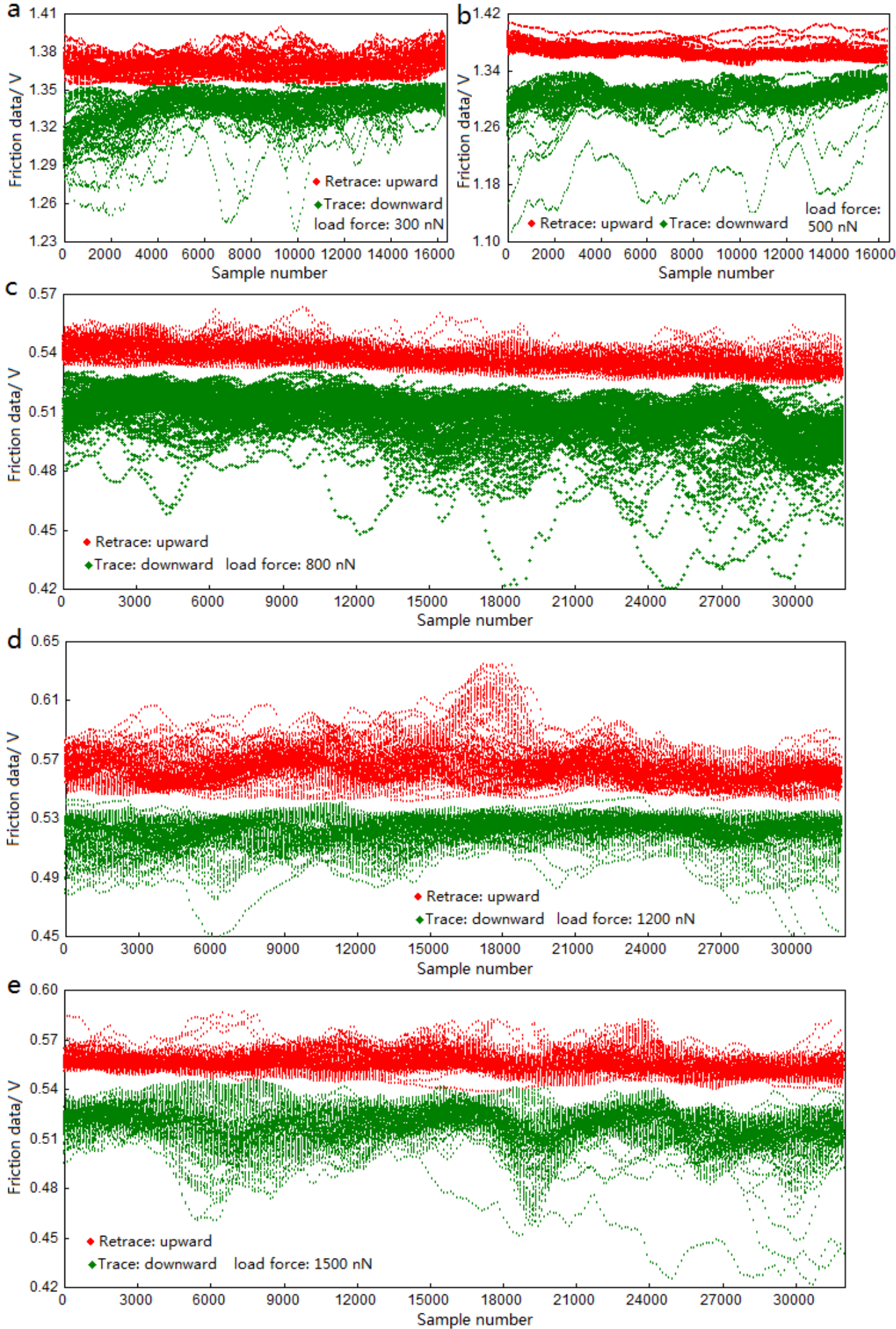

FIGURE 2. Friction data generated by the AFM cantilever on the wax coverings along downward (Trace, towards digestive zone) and upward (Retrace, towards peristome) directions. Images were used to show the difference in the friction data obtained from Trace and Retrace scanning. The wax coverings were scanned with the AFM apparatus in two batches, and the AFM cantilever was readjusted for each batch, thus values of the longitudinal coordinates were different 


\section{MICROMORPHOLOGY OF WAX COVERINGS}

Highly similar to the descriptions in previous studies (Gaume et al. 2004; Gorb \& Gorb 2006; Gorb et al. 2005; Riedel et al. 2007, 2003; Wang \& Zhou 2014; 2010), our SEM micrographs of the slippery zone (Figure 3(a)) showed the wax coverings to be covered by a layer of dense and continuous wax coverings, along with a great number of singly scattered lunate cells (Figure 3(b)). Each lunate cell corresponds to an enlarged guard cell with both ends bent downward, namely towards the digestive zone, generating a crescent-formed outline with a convex asymmetrical topography (Figure 3(b)). The wax coverings consist of discernible and platelet- shaped crystals with irregular profile, arranging rather dense on the slippery zone and mostly overlapping each other, which makes the generated cavities are nearly undistinguishable (Figure 3(c)). Further, the wax coverings without sample treatment (the critical point drying and sputter-coating) showed their surface topography to possess a rather significant similarity in different directions (Figure 3(b)). When the wax coverings were inverted from upward to downward, the difference in their general morphology could hardly be detected (Figure 3(c)). The results probably indicate that the surface morphology of the wax coverings has isotropic properties.
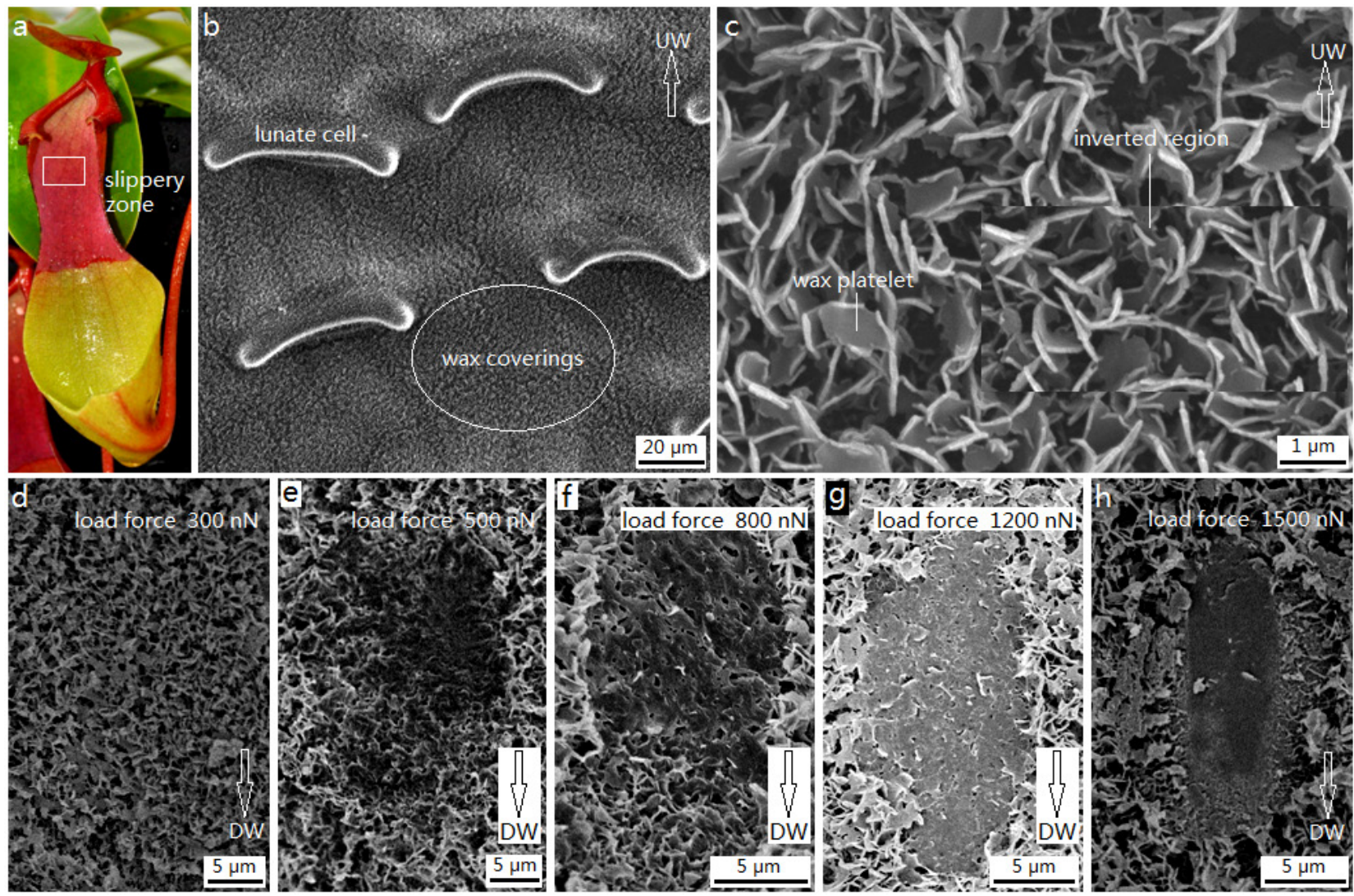

FIGURE 3. Microstructures of the wax coverings (a) SEM examined region of the slippery zone, (b) micromorphology of the original (without critical point drying and sputter-coated) slippery zone, (c) micromorphology of the wax coverings, and (d-h) damage degree of the scanned wax coverings under different load forces. UW/DW: upward/downward direction

Micromorphology of the scanned wax coverings was examined to investigate the damage degree under different load forces. Almost no detectable damage was shown when applying the load force of $300 \mathrm{nN}$ (Figure 3(d)). This result extended a previous investigation, as the load force up to $250 \mathrm{nN}$ could not damage the wax coverings (Scholz et al. 2010). When the AFM cantilever was sequentially applied with the load force of 500, 800, and $1200 \mathrm{nN}$, the wax coverings showed observable damages. However, the residual wax coverings still were present on these scanned regions (Figure 3(e)$3(\mathrm{~g})$ ), indicating only part of the wax coverings could be damaged under these load forces. The damage degree became much higher when applying the load force of 1500 $\mathrm{nN}$, causing the wax coverings to disappear completely and present the substrate of slippery zone (Figure 3(h)). 
The results suggested that the wax coverings cannot be destroyed when the AFM cantilever is applied with the load force below $300 \mathrm{nN}$, and partly destroyed when the load force ranges from 500 to $1200 \mathrm{nN}$, and completely destroyed when the load force exceeds $1500 \mathrm{nN}$.

\section{CONTRIBUTION OF WAX COVERINGS TO ANISOTROPY OF SLIPPERY ZONE}

Lunate cells depend on their anisotropic structure to surely cause the slippery zone to exhibit rather significant surface anisotropy, generating a considerable difference in the attachment behaviors of insects. Authors initially postulated that this anisotropy enables insect claws to grasp when turned the slippery zone upside down (Bobisut 1910; Knoll 1914). Behavioral observation has certified this postulation, as the lunate cells rely on their vertical-oriented morphology to prohibit insect claws from grasping, though such structure provides steady anchorages for insect claws to generate effective attachment when the slippery zone is inverted (Gaume et al. 2004, 2002; Gorb \& Gorb 2011). Mechanical analyses showed theoretical explanations for the conspicuous difference in attachment capability, as the lunate cells depend on their small slope angle (about $23^{\circ}$ ) in upward direction to preclude the insect claws from generating mechanical interlock, whereas the inverted ones depend on their large slope angle (about $76^{\circ}$ ) in downward direction to enhance the mechanical interlock (Wang et al. 2016). In these studies, the contribution of wax coverings to the anisotropy of slippery zone is ignored.

In our study, friction data of the wax coverings along downward and upward directions were obtained, attempting to characterize the frictional properties (anisotropy or isotropy) of wax coverings. Scholz has conducted the AFM scanning of wax coverings, but only presented the maximal value of load force which the wax coverings can withstand (Scholz et al. 2010). Therefore, our investigation provides original findings to analyze the frictional properties of wax coverings. When the AFM cantilever was applied with a load force of $300 \mathrm{nN}$, friction data along the two directions showed rather unobvious difference $(2.56 \%)$ (Table 1$)$, and the scanned wax coverings presented no detectable damage (Figures 3(d) and 4(a)). The results indicate the surface morphology of wax coverings cannot make the AFM cantilever present observably anisotropic friction data. Further, the surface morphology of unprocessed wax coverings showed a highly observable uniformity (Figure 3(b)), and the difference in surface morphology cannot be detected when inverting the wax coverings (Figure 3(c)). Thus, the wax coverings hardly show the anisotropic properties depending on their surface morphology.

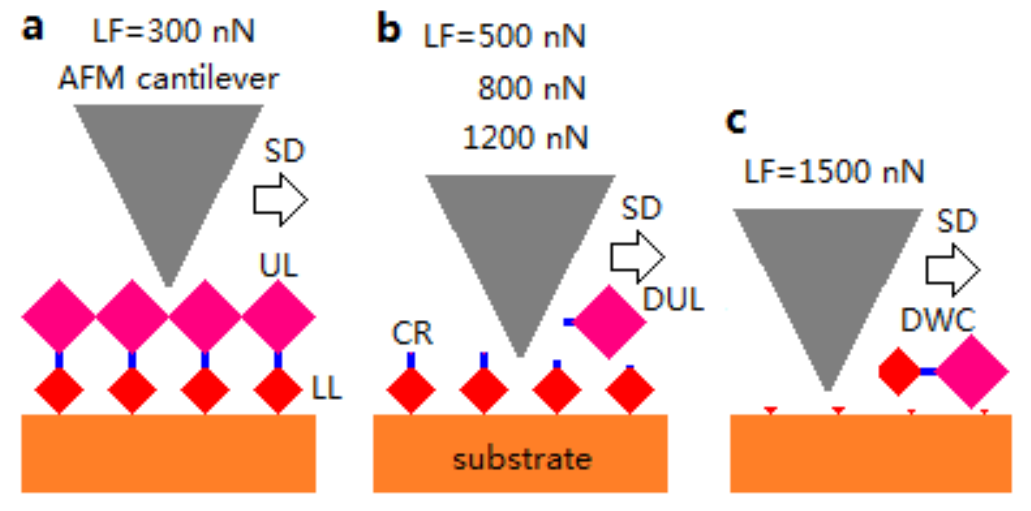

FIGURE 4. Sketches showing the structure of wax coverings and the damage provided by AFM cantilever with different load forces. (a) the wax coverings consist of an upper layer (UL), a lower layer (LL) and a connecting rod (CR) between the two layers, and the load force (LF) of $300 \mathrm{nN}$ generates no detectable damage to the wax coverings, (b) the load forces of 500, 800, and $1200 \mathrm{nN}$ generate observable damage to the upper layer of wax coverings, and (c) the load force of $1500 \mathrm{nN}$ destroys the wax coverings completely. SD: scanning direction of AFM cantilever, DUL: destroyed upper layer of wax coverings, and DWC: destroyed wax coverings

When applying the load forces of 500, 800, and $1200 \mathrm{nN}$, the differences in friction data became much more observable $(4.83,5.98$, and $8.40 \%$ respectively) (Table 1), and the AFM cantilever partly destroyed the wax coverings (Figure 3(e)-3(g)). The wax coverings consist of an upper layer and a lower layer, and the two layers connect with each other via thin connecting rods
(Gorb et al. 2005). Therefore, under these load forces, the AFM cantilever probably destroyed the upper layer of wax coverings (Figure 4(b)), and the connection characteristic is potentially responsible for the differences in friction data. However, the differences are considerably weak to be considered as convincing evidence to declare the anisotropy of wax coverings. That is, the structural 
characteristic cannot bring the anisotropy. The difference in friction data decreased $(7.47 \%)$ (Table 1) slightly when increasing the load force to $1500 \mathrm{nN}$, and the wax coverings were destroyed completely (Figures 3(h) and 4(c)). To a certain extent, it is the substrate of slippery zone to contact with the AFM cantilever and generates the friction data. Therefore, these different friction data cannot be considered as convincing evidence to characterize the anisotropy. In another aspect, under the load force of $1500 \mathrm{nN}$, the AFM cantilever could damage the entire structures of wax coverings, causing the separation of wax coverings from the substrate of slippery zone. The separated wax coverings generated the contamination to the AFM cantilever and acted as a lubricant, resulting in the decrease of friction data (Figures 2(d) and 2(e))

\section{CONCLUSION}

In summary, via the AFM scanning, we obtained the friction data to characterize the frictional properties (anisotropy or isotropy) of wax coverings. Friction data along upward and downward directions were different when the AFM cantilever was applied with a load force, and the difference (2.56-8.40\%) change with the variation of the applied load force (300-1500 $\mathrm{nN}$ ). SEM data showed the original morphology of wax coverings has a highly observable uniformity, and damage degree of the scanned wax coverings changed significantly when varying the load force. We declare that wax coverings depend on their surface morphology and structural characteristic to cause the AFM cantilever to generate different friction data along downward and upward directions, but the difference is considerably weak to declare the surface anisotropy. Our study has well characterized the frictional properties of the wax coverings of slippery zone in $N$. alata, and it fully shows the anisotropy mechanism of slippery zone and motivates the slippery zone to be a bionic porotype for developing anisotropic surfaces.

\section{ACKNOWLEDGEMENTS}

The authors sincerely acknowledge the financial supports from the National Natural Science Foundation of China (51205107), the Top Talents Program of Hebei Higher Education (BJ2017011) and the Tribology Science Fund of State Key Laboratory of Tribology (SKLTKF16B01).

\section{REFERENCES}

Bauer, U., Willmes, C. \& Federle, W. 2009. Effect of pitcher age on trapping efficiency and natural prey capture in carnivorous Nepenthes rafflesiana plants. Ann. Bot. 103(8): 1219-1226.

Benz, M.J., Gorb, E.V. \& Gorb, S.N. 2012. Diversity of the slippery zone microstructure in pitchers of nine carnivorous Nepenthes taxa. Arthropod-Plant Inte. 6(1): 147-158.

Bobisut, O. 1910. Über den funktionswechsel der spaltöffnungen in der gleitzone der Nepenthes-kannen, Akad Wiss, Wien Sitzungsber, Math-Naturwiss. Kl. Abt. 1(1): 3-10.
Bonn, H.F. \& Federle, W. 2004. Insect aquaplaning: Nepenthes pitcher plants capture prey with the peristome, a fully wettable water-lubricated anisotropic surface. Proc. Natl. Acad. Sci. USA. 101: 14138-14143.

Chen, H.W., Zhang, L.X., Zhang, P.F., Zhang, D.Y., Han, Z.W. \& Jiang, L. 2017. A novel bioinspired continuous unidirectional liquid spreading surface structure from the peristome surface of Nepenthes alata. Small 13(4): 1670 1676.

Chen, H.W., Zhang, P.F., Zhang, L.W., Liu, H.L., Jiang, Y., Zhang, D.Y., Han, Z.W. \& Jiang, L. 2016. Continuous directional water transport on the peristome surface of Nepenthes alata. Nature 532(7597): 85-89.

Ellison, A.M. \& Gotelli, N.J. 2001. Evolutionary ecology of carnivorous plants. Trends Ecol. Evol. 16(11): 623-629.

Ellison, A.M. \& Gotelli, N.J. 2009. Energetics and the evolution of carnivorous plants-Darwin's most wonderful plants in the world. J. Exp. Bot. 60(1): 19-42.

Gaume, L. \& Giusto, B.D. 2009. Adaptive significance and ontogenetic variability of the waxy zone in Nepenthes rafflesiana. Ann. Bot. 104(7): 1281-1291.

Gaume, L., Perret, P., Gorb, E., Gorb, S., Labat, J.J. \& Rowe, N. 2004. How do plant waxes cause flies to slide? Experimental tests of wax-based trapping mechanisms in three pitfall carnivorous plants. Arth. Struct. Dev. 33(1): 103-111.

Gaume, L., Gorb, S. \& Rowe, N. 2002. Function of epidermal surfaces in the trapping efficiency of Nepenthes alata pitchers. New Phytol. 156(3): 479-489.

Gorb, E.V. \& Gorb, S.N. 2011. The effect of surface anisotropy in the slippery zone of Nepenthes alata pitchers on beetle attachment. Beilstein. J. Nanotechnol. 2(1): 302-310.

Gorb, E. \& Gorb, S. 2006. Physicochemical properties of functional surface in pitchers of the carnivorous plant Nepenthes alata blanco (Nepenthaceae). Plant Biol. 8(6): 841-848.

Gorb, E., Haas, K., Henrich, A., Enders, S., Barbakadze, N. \& Gorb, S. 2005. Composite structure of the crystalline epicuticular wax layer of the slippery zone in the pitchers of the carnivorous plant Nepenthes alata and its effect on insect attachment. J. Exp. Biol. 208(24): 4651-4662.

Juniper, B.E. \& Burras, J.K. 1962. How pitcher plant trap insects. New Sci. 269(1): 75-77.

Knoll, F. 1914. Über die ursache des ausgleitens der insektenbeine an wachsbedeckten pflanzenteilen. Jahrb. Wiss. Bot. 54(12): 448-497.

Koch, K., Bhushan, B. \& Barthlott, W. 2009. Multifunctional surface structures of plants: An inspiration for biomimetics. Prog. Mater. Sci. 54(2): 137-178.

Moran, J.A. 1996. Pitcher dimorphism, prey composition and the mechanisms of prey attraction in the pitcher plant Nepenthes rafflesiana in Borneo. J. Ecol. 84(4): 515-525.

Moran, J.A. \& Clarke, C.M. 2010. The carnivorous syndrome in Nepenthes pitcher plants: Current state of knowledge and potential future directions. Plant Signal. Behav. 5(6): 644-648.

Moran, J.A., Booth, W.E. \& Charles, J.K. 1999. Aspects of pitcher morphology and spectral characteristics of six Bornean Nepenthes pitcher plant species: Implications for prey capture. Ann. Bot. 83(5): 521-528.

Page, O.T. \& Lennon, K.A. 1999. Structure and development of the pitchers from the carnivorous plant Nepenthes alata (Nepenthaceae). Am. J. Bot. 86(10): 1382-1390. 
Pant, D.D. \& Bhatnagar, S. 1977. Morphological studies in Nepenthes (Nepenthaceae). Phytomorphology 27(1): 13-34.

Riedel, M., Eichner, A. \& Jetter, R. 2003. Slippery surfaces of carnivorous plants: Composition of epicuticular wax crystals in Nepenthes alata Blanco pitchers. Planta 218(1): 87-97.

Riedel, M., Eichner, A., Meimberg, H. \& Jetter, R. 2007. Chemical composition of epicuticular wax crystals on the slippery zone in pitchers of five Nepenthes species and hybrids. Planta 225(6): 1517-1534.

Scholz, I., Bückins, M., Dolge, L., Erlinghagen, T., Weth, A., Hischen, F., Mayer, J., Hoffmann, S., Riederer, M., Riedel, M. \& Baumgartner, W. 2010. Slippery surfaces of pitcher plants: Nepenthes wax crystals minimize insect attachment via microscopic surface roughness. J. Exp. Biol. 213(7): $1115-1125$.

Thornham, D.G., Smith, J.M., Grafe, T.U. \& Federle, W. 2012. Setting the trap: Cleaning behavior of Camponotus schmitzi ants increases long-term capture efficiency of their pitcher plant host Nepenthes bicalcarata. Funct. Ecol. 26(1): 11-19.

Wang, L.X. \& Zhou, Q. 2016. Surface hydrophobicity of slippery zones in the pitchers of two Nepenthes species and a hybrid. Sci. Rep. 6: 19907.

Wang, L.X. \& Zhou, Q. 2014. Nepenthes pitchers: Surface structure, physical property, anti-attachment function and potential application in mechanical controlling plague locust. Chin. Sci. Bull. 59(21): 2513-2523.

Wang, L.X. \& Zhou, Q. 2011. Friction force of locust Locusta migratoria manilensis (Orthoptera, Locustidae) on slippery zones surface of pitchers from four Nepenthes species. Tribol. Lett. 44: 345-353.

Wang, L.X. \& Zhou, Q. 2010. Numerical characterization of surface structures of slippery zone in Nepenthes alata pitchers and its mechanism of reducing locust's attachment force. Adv. Nat. Sci. 2(3): 152-160.
Wang, L.X., Dong, S.Y. \& Zhou, Q. 2016. Slippery surface of Nepenthes alata pitcher: The role of lunate cell and wax crystal in restricting attachment ability of ant Camponotus japonicus Mayr. J. Bionic. Eng. 13(3): 373-387.

Wang, L.X., Zhou, Q., Zheng, Y.J. \& Xu, S.Y. 2009. Composite structure and properties of pitcher surface of carnivorous plant Nepenthes and its influence on insect attachment system. Prog. Nat. Sci. 19(12): 1657-1664.

Wang, Z.B., Heng, L.P. \& Jiang, L. 2018a. Effect of lubricant viscosity on the self-healing properties and electrically driven sliding of droplets on anisotropic slippery surfaces. J. Mater. Chem. A. 6(8): 3414-3421.

Wang, Z.B., Liu, Y., Guo, P., Heng, L.P. \& Jiang, L. 2018b. Photoelectric synergetic responsive slippery surfaces based on tailored anisotropic films generated by interfacial directional freezing. Adv. Funct. Mater. 28: 1801310.

Wong, T.S., Kang, S.H., Tang, S.K.Y., Smythe, E.J., Hatton, B., Grinthal, A. \& Aizenberg, J. 2011. Bioinspired self-repairing slippery surfaces with pressure-stable omniphobicity. Nature 477(7365): 443-447.

Zhang, P.F., Chen, H.W. \& Zhang, D.Y. 2015. Investigation of the anisotropic morphology-induced effects of the slippery zone in pitchers of Nepenthes alata. J. Bionic Eng. 12(1): 79-87.

School of Mechanical Engineering

Hebei University of Science and Technology

Shijiazhuang 050018

People's Republic of China

*Corresponding author; email: wanglx@hebust.edu.cn

Received: 8 April 2019

Accepted: 13 March 2020 